\title{
Taste as a social sense: rethinking taste as a cultural activity
}

Susanne Højlund

\begin{abstract}
This article outlines what it means to see taste as a social sense, that means as an activity related to socio-cultural context, rather than as an individual matter of internal reflection. Though culture in the science of taste is recognized as an influential parameter, it is often mentioned as the black box, leaving it open to determine exactly how culture impacts taste, and vice versa, and often representing the taster as a passive recipient of multiple factors related to the local cuisine and culinary traditions. By moving the attention from taste as a physiological stimulus-response of individuals to tasting as a shared cultural activity, it is possible to recognize the taster as a reflexive actor that communicates, performs, manipulates, senses, changes and embodies taste-rather than passively perceives a certain experience of food. The paper unfolds this anthropological approach to taste and outlines some of its methodological implications: to map different strategies of sharing the experience of eating, and to pay attention to the context of these tasting practices. It is proposed that different taste activities can be analysed through the same theoretical lens, namely as sharing practices that generates and maintains a cultural understanding of the meaning of taste.
\end{abstract}

Keywords: Taste, Tasting, Culture, Practice, Sharing, Context

\section{Taste as a social sense}

We eat together. Although there is a constant worry that the sociality of the meal is disappearing, this is rather a myth than reality [1]. Commensality is still highly valued across cultures, even though this value is distributed differently [2]. But stating that eating is a social activity does not in itself explain how taste becomes social or culture becomes taste. As it is not the actual substance of the food that you are sharing, it is still individual what you put into your mouth, what you chew, ingest and perceive. This could lead to the argument that to analyse taste as a cultural phenomenon means, primary, to explore how individuals interpret symbolic meanings of food, e.g. the aesthetic judgement of quality in the Kantian way [3], or how the eater interpret food taboos, definitions and cultural schemes of food rules related to different cultures [4]. But there is still a missing link in explaining how this symbolism becomes a habit or a certain taste preference. The French sociologist Pierre Bourdieu has an influential contribution to this with his concept of lifestyle [5] stressing the need to focus not only on ideas and discursive

Correspondence: etnosh@cas.au.dk

Department of Anthropology, Aarhus University, Moesgaard Alle 2, Højbjerg, DK-8270 Aarhus, Denmark models but also on practice. He explains taste preferences (both the aesthetic judgements and the food choice/other types of consumption) as linked to the distribution of cultural, social and economic capital, and the learning of these preferences as a consequence of social practice [6]. This practice generates a habitus, he argues, that guides our choices more or less unconscious. But it leaves us with a rather passive actor [7] and do not enable us to study how one can change taste preferences [8]. Nevertheless it encourages us to see taste as a social sense, as a shared judgement, learned by actively doing taste rather that passively inheriting it from 'culture' [9].

\section{Sharing taste}

In order to move the attention from the privacy of the mouth and the subjective, internal reflections to the public space of sharing the experience of eating, it is necessary to develop methodological approaches and models of analyses that can shed light on the social processes of tasting. Many food anthropologists and sociologists are engaged in this kind of analyses focusing on food practices in relation to cultural context e.g. $[10,11]$. But it is seldom with an explicit focus on processes of tasting. Tasting is part of eating and drinking, 
but not similar hereto. With a focus on tasting rather than on eating, we stress the use of the senses and the judgement of food quality as one dimension of eating. What can be gained from seeing tasting as a practice is a way to understand how ideas of food quality and preferences for certain food stuffs are brought into the social and thereby being object for others and possible to share. I propose, thus, that outlining this field of research would include a mapping of sharing practices, seeing taste not only as something that goes into your body but also the opposite way [8].

From this analytical approach follows that different sharing practices could be studied under the same theoretical umbrella. Such different activities could be: using bodily techniques as e.g. eating with your fingers [12]; intentionally manipulating taste through cooking [13]; talking about taste [14] —-from the everyday dialogues in the family to the professional chef's talks on TV [15]; to the writing of food blogs and cook books [16]; using digital media as e.g. sharing food photos at Instagram; arranging food festivals and wine tasting [17]; providing taste education in schools [18] etc. I propose that such different activities can be seen as part of the same social activity: the activity of making taste public $[11,19]$. Understanding how taste is externalised through culture will make it possible to also analyse how cultural taste preferences are internalised [20]. I am thus pointing to a research field of taste that focuses on the mediated space between food and eater, and an overall research question that asks how this space is constantly created and recreated through cultural mediation [21].

\section{The cultural activity of tasting}

I have in this short Opinion outlined what it could mean to see taste as a social sense and stressed that it includes an analysis of tasting as a cultural activity, rather than having an isolated focus on what a product is doing to your taste buds [7]. This is also a shift from taste to tasting. But tasting is not just tasting; tasting means different things in different contexts: The taste of mussels is not the same for a restaurant guest at a gourmet restaurant as for a fisherman in a poor part of the country side [22]. The taste of mussels will be shared in very different ways in these two situations. Mapping strategies of sharing would, thus, not be more than a long list of different types of practices if not the context is taken into account. What a certain taste sharing practice means is related to the situational as well as to the geographical, political and historical context. In order to interpret why people share certain tastes and not others, why they talk about taste in this way and not another etc. one needs to pay attention to the situations and conditions the activity of tasting take place within. This view of senses as cultural is well described, e.g. [23] what is lesser acknowledged is that the cultural activity of tasting has this double function: being both influenced by and influencing the social.

This active use of the sense of taste is difficult to grasp perhaps because the concept of taste itself does not give us many chances to distinguish between different taste situations. It is remarkable how, e.g. the sense of vision has many related words that position the actor in relation to context and activity: you can watch, stare, scan, observe, see, notice, gaze; all these notions express how individuals are using different techniques of seeing [24] in different situations. With these concepts, one can imagine how a person puts his or her sense of vision into play in a social situation-a staring person uses this sense in another way than a person observing or gazing. With the concept of taste we do not-at the moment-have the same different possibilities to conceptualise the act of tasting in relation to context.

One of the ways forward to gain knowledge about how taste and culture influence each other is to explore how the taster is doing the act of tasting in different social situations. This will be a matter of empirical analyses studying the activities and social strategies of sharing taste: from the preparation of tastes to the moment where a taste meets a body-mediated or material-to the study of the contexts this meeting takes place within, and the analysis of which practices of taste sharing are generated under certain circumstances. Taste then becomes an experience that not only goes into the mind of the subject but also contributes to the common creation of knowledge.

\section{Competing interests}

The author declares that she has no competing interests.

\section{Acknowledgements}

I am grateful to professor emerita Carole Counihan for the inspiration, especially in relation to her and Psyche Williams-Forson's book Taking Food Public.

Received: 2 December 2014 Accepted: 2 December 2014

Published: 26 February 2015

\section{References}

1. Murcott A: Myth and Realities: A New Series of Public Debates 9th. 2010.

2. Fischler C: Commensality, society and culture. Soc Sci Inf 2011, 50(3-4):528-548.

3. Kant I: Kritik af dømmekraften. Det lille Forlag: Frederiksberg; 2007.

4. Douglas M: Purity and Danger. An Analysis of Concepts of Pollution and Taboo. London: Routledge and Paul Keegan; 1966.

5. Bourdieu P: Distinction. A Social Critique of the Judgement of Taste. Cambridge, MA United States of America: Harvard University Press; 1984

6. Bourdieu P: The Logic of Practice. Stanford, California: Stanford University Press; 1980.

7. Teil G, Hennion A: Discovering quality or performing taste? A sociology of the amateur. In Qualities of Food. Edited by Harvey M, McMeekin A Warde A. Manchester: Manchester University Press; 2004:19-29.

8. Korsmeyer C: Making Sense of Taste. Food and Philosophy. Ithaca and London: Cornell University Press; 2002.

9. Gherardi S: Practice? It's a matter of taste! Manag Learn 2009, 40(5):535-550.

10. Abbots EJ, Lavis A: Why We Eat. How We Eat. Contemporary Encounters between Foods and Bodies. Surrey and Burlington: Ashgate Publishing Company; 2013. 
11. Williams-Forson P, Counihan C: Taking Food Public. Redefining Foodways in a Changing World. New York and Oxon: Routledge; 2012.

12. Mann A, Mol AM, Satalkar P, Savirani A, Selim N, Sur M, Yates-Doerr E: Mixing methods, tasting fingers. Notes on an ethnographic experiment. HAU: J Ethnographic Theor 2011, 1(1):221-243.

13. Stroller P: The Taste of Ethnographic Things. The Senses in Anthropology. Philadelphia: University of Pennsylvania; 1989.

14. Kuipers JC: Matters of taste in Weyéwa. Anthropol Ling 1993, 1(4):538-555.

15. Leer J, Povlsen KK: Media Food. East Anglia: Ashgate; 2015.

16. Povlsen KK: Karoline, koen og digitale måltider. In Det gode madliv: Karoline, maden og måltidet $i$ kulturen. Edited by Færch T, Møller M, Anne Kirstine Hougaard AK, Viby J. ; 2008:95-103.

17. Vannini P, Ahluwalia-Lopez G, Waskul D, Gottschalk S: Performing taste at wine festivals: a somatic layered account of material culture. Qual Inq 2010, 16(5):378-396.

18. Strong J (Ed): Educated Tastes: Food, Drink and Connoisseur Culture. Lincoln: University of Nebraska Press; 2011.

19. Chau AY: The sensorial production of the social. Ethnos J Anthropol 2008, 73(4):485-504.

20. Berger PL, Luckmann T: The Social Construction of Reality: A Treatise in the Sociology of Knowledge. New York: Anchor Books; 1968.

21. Boyer D: From media anthropology to the anthropology of mediation. In SAGE Handbook of Social Anthropology. London: SAGE; 2012.

22. Murcott A: Interlude. Reflections on the elusiveness of eating. In Why We Eat, How We Eat. Contemporary Encounters between Foods and Bodies. Edited by Abbots EJ, Lavis A. Surrey and Burlington: Ashgate Publishing Company; 2013

23. Howes D (Ed): Empire of the Senses: the Sensual Culture Reader. Oxford, New York: Berg; 2006.

24. Hansen HP: I græensefladen mellem liv og død: en kulturanalyse af sygeplejen på en onkologisk afdeling. København: Munksgaard; 2002.

\section{Submit your next manuscript to BioMed Central and take full advantage of:}

- Convenient online submission

- Thorough peer review

- No space constraints or color figure charges

- Immediate publication on acceptance

- Inclusion in PubMed, CAS, Scopus and Google Scholar

- Research which is freely available for redistribution 